UDC 614.253.1:614.2(477.44)

DOI: 10.15587/2519-4798.2017.94087

\title{
THE INFLUENCE OF COMPETITION ON QUALITY OF HOSPITAL TREATMENT FROM PHYSICIAN BEHAVIOR PERSPECTIVE (THEORETICAL MODEL VERIFICATION WITH CASE PRESENTATION FROM VINNITSA, UKRAINE)
}

\author{
(C) I. Yaremena, O. Ocheredko
}

\begin{abstract}
Емпірично перевірені висновки теоретичної моделі поведінки лікаря щзодо можливого зниження якості лікування за умови ринкової монополії. Теоретична модель розкрила одну з головних причин иьому - збільшення клінічних годин лікарем за рахунок параклінічних, щзо неминуче загрожує якості лікування. Емпіричний фрейм базувався на значних перевантаженнях пацієнтами лікарів деяких стаціонарних відділень в процесі реформи охорони здоров'я у м. Вінниці
\end{abstract}

Ключові слова: якість лікування, тривалість періоду до наступної госпіталізащії, поведінка лікаря, конкуренція

\section{Introduction}

The quantity and quality of physician services are provided by physician's decision. Physician operates with double-purpose. By rendering utilities of patient he pursues his own. The lack of ad hoc competition entices physician to behave on his discretion. On the other hand, the lack of responsibility supported by high patient load may aggravate aberrations in physician's behavior. We developed the behavioral model based on maximization of physician's utility curve under non-linear budget constraints and applied Slutsky equations that decompose virtual price effects into substitution and income effects [1]. The main conclusions of the model provide the decrease in volume of services rendered by physician, as well as the increase in paraclinical hours instead of clinical hours under competition. Furthermore lengthening in hospital stays anticipated as well. Thereby, physician shifts toward activities that improve performance by spending more time on each procedure. The closest supports of our theoretical findings are the studies of Bernard Fortin and Damien Echevin [2, 3].

\section{Case presentation}

Evidences from hospitals records appeared to sustain theoretical propositions. Our empirical set captured situation in the city of Vinnitsa, Ukraine. Resulting from voluntary decrease of hospital bed capacity, decrease in competition, and increase in patient load per physician perfectly suited empirical verification. We indeed revealed that under increased load of patients physician significantly decreases length of staying (LOS) [4]. Analysis of cohort of gastroenterological patients substantiated the preposition of theoretical model in relation between the quality of services and time spent on each service. These effects were strong and probably not anticipated by policy makers. Moreover, the increase in patients' hospital LOS is likely to be seen as a perverse impact of any reform given health care expenses. Actually, a large number of health care policies mainly aim at reducing hospital LOS. Despite the numerous debates and controversial empirical evidences based on the managed care setups, the question
"Does it compromise quality?" still remains problematic. This fact together with peculiarities of hypothesis formulation in transition economy slipped from researchers' attention constitutes uniqueness of the study.

To bring some certainty, we referred to natural experiment. In a process of health reform in Vinnitsa city, distortions in hospital care provision were notable across hospitals though rather stable general situation. It appeared that one of the greatest shift in admission rate occurred in city hospital No.1 in 2009 due to city hospital No.2 transformation into emergency hospital, so that city hospital No.1 took over patients without increase in capacity and staff. Therapeutic departments experienced the brunt of increase in patients load. We collected the data by stratified panel design between departments of city hospital No.1 starting from 2008 with randomized inclusion. Thereafter, to sustain statistical power, we got on with total coverage up to January 31, 2012. Thus, we considered 2680 admission cases totally.

Length of period between subsequent admissions (LBA) considered as the measure of treatment quality. LBA equivalents to risk of next admission and readmission and bares evidence on quality of treatment at precedent admission. Some researchers considered LBA as proxy measure of morbidity [5]. LBA has more to it as a measure of treatment quality. Length of hospital staying regarded as the main driver of health expenditures. Nevertheless, in case the prolongation of staying gains the quality one should provide the economizing of alternative costs due to the substitution by out-patient services in perspective.

\section{Aim of research}

Given aforementioned in case the prolongation of staying gains quality indeed, we expect positive correlation between length of hospital staying and LBA. Confirmation of such correlation would support the proposition of physician behavior model that stipulates deterioration in treatment quality advocated in part by established accent on clinical hours instead of paraclinical resulting from the lack of competition, situation sometimes aggravated with high patient load. 


\section{Material and Methods}

To check the deduction stemming from the theoretical model of physician behavior on part of possible impairment of quality under market monopoly we exploited competing risk modeling having in mind 2 types of subsequent admissions:

- the same cause as in previous admission;

- different cause.

It ensures us to use two types of censoring, both informative and non-informative. The non-informative censoring tells on termination of tracing before the next admission. The majority of cases demonstrated non-informative censoring. Informative censoring denotes admission due to the different cause then previous. Absence of censoring refers to subsequent admission due to the same cause as previous. Yet another, third type of censoring related to lethality. It's known as terminal event censoring. It's actually the informative censoring that precludes any following censoring or risk accumulation. If we denote $\mathrm{T}_{\mathrm{ij}}$ as $\mathrm{j}^{\text {th }}$ admission episode in $\mathrm{i}^{\text {th }}$ patient with the same cause as previous $Y_{i j}$ - with different cause, $\mathrm{C}_{\mathrm{ij}}$ - censoring because of termination of tracing, each period between successive admissions can be classified by:

$$
\delta_{i j}=\left\{\begin{array}{lll}
1 & \text { if } \quad T_{i j} \leq \min \left\{C_{i j}, Y_{i j}\right\}, \\
0 & \text { if } \quad C_{i j} \leq \min \left\{T_{i j}, Y_{i j}\right\}, \\
-1 & \text { if } \quad Y_{i j} \leq \min \left\{T_{i j}, C_{i j}\right\},
\end{array}\right.
$$

so that $\delta_{\mathrm{ij}}=1$ in absence of censoring, $\delta_{\mathrm{ij}}=0$ - non-informative censoring, $\delta_{\mathrm{ij}}=-1-$ informative censoring.
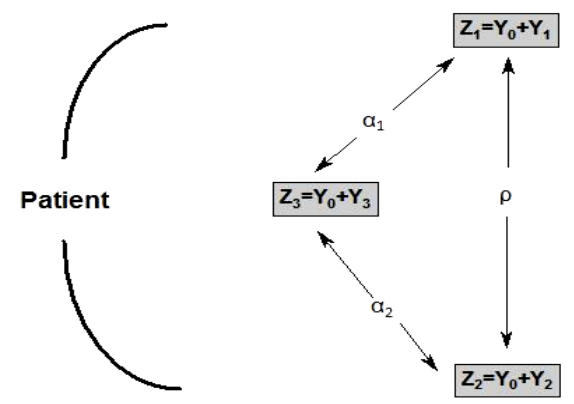

Same cause

Lethal case

Fig. 1. Frailties composition under competing risk

Fig. 1 illustrates frailty composition under competing risk. Set of events includes:

1) admission due to the same cause with frailty $Z_{1}$ with gamma distribution resulted from sum of independent gamma distributed variables $\mathrm{Y}_{0}$ and $\mathrm{Y}_{1}$;

2) admission due to the different cause with gamma distributed frailty $Z_{2}$ resulted from sum of independent gamma distributed variables $\mathrm{Y}_{0}$ and $\mathrm{Y}_{2}$;

3) terminal event with gamma distribution resulted from sum of independent gamma distributed variables $\mathrm{Y}_{0}$ and $\mathrm{Y}_{3}$.

The mutual variable $Y_{0}$ serves commonality in individual risks. Indeed, all three events induced by health problem of particular patient, the fact captured by $\mathrm{Y}_{0}$. To get into practicalities we used:

$$
\begin{aligned}
& \mathrm{Z}_{1}=\frac{\lambda_{0}}{\lambda_{1}} \mathrm{Y}_{0}+\mathrm{Y}_{1} \sim \mathrm{Ga}\left(\mathrm{k}_{0}+\mathrm{k}_{1}, \mathrm{k}_{0}+\mathrm{k}_{1}\right), \\
& \mathrm{Z}_{2}=\frac{\lambda_{0}}{\lambda_{2}} \mathrm{Y}_{0}+\mathrm{Y}_{2} \sim \mathrm{Ga}\left(\mathrm{k}_{0}+\mathrm{k}_{2}, \mathrm{k}_{0}+\mathrm{k}_{2}\right), \\
& \lambda_{1}=\mathrm{k}_{0}+\mathrm{k}_{1}, \\
& \lambda_{2}=\mathrm{k}_{0}+\mathrm{k}_{2} .
\end{aligned}
$$

This ensures simple first and second moments of frailties distributions:

$$
\begin{aligned}
& \mathrm{EZ}_{1}=\mathrm{EZ}_{2}=1, \\
& \mathrm{~V}\left(\mathrm{Z}_{1}\right)=\frac{1}{\lambda_{1}}=\sigma_{1}^{2}, \mathrm{~V}\left(\mathrm{Z}_{2}\right)=\frac{1}{\lambda_{2}}=\sigma_{2}^{2} .
\end{aligned}
$$

Therefore, co-variation between $Z_{1}$ and $Z_{2}$ is:

$$
\begin{aligned}
& \operatorname{cov}\left(Z_{1}, Z_{2}\right)=\operatorname{cov}\left(\frac{\lambda_{0}}{\lambda_{1}} Y_{0}+Y_{1} \frac{\lambda_{0}}{\lambda_{2}} Y_{0}+Y_{2}\right)= \\
& =\frac{\lambda_{0}^{2}}{\lambda_{1} \lambda_{2}} \mathrm{~V}\left(\mathrm{Y}_{0}\right)=\frac{\lambda_{0}^{2}}{\lambda_{1} \lambda_{2}} \frac{\mathrm{k}_{0}}{\lambda_{0}^{2}}=\frac{\mathrm{k}_{0}}{\left(\mathrm{k}_{0}+\mathrm{k}_{1}\right)\left(\mathrm{k}_{0}+\mathrm{k}_{2}\right)} .
\end{aligned}
$$

With simple correlation formulae ( $\rho)$ :

$$
\rho=\frac{\operatorname{cov}\left(Z_{1}, Z_{2}\right)}{\sqrt{V\left(Z_{1}\right) V\left(Z_{2}\right)}}=\frac{k_{0}}{\sqrt{\left(k_{0}+k_{1}\right)\left(k_{0}+k_{2}\right)}} .
$$

Specification of events rendered by particular independent variables $Y_{1}, Y_{2}$, and $Y_{3}$. Event specification also ingrained into specific linear predictors.

Thereby, competing risks incorporated into mixed proportional hazard model (MPH) by:

- censoring system (1), incorporating each admission due to the same cause precludes admission due to the different cause and counterwise; lethality introduces another competing risk that upon happening terminates exposure to competing risks;

- expression of $Z_{1}$ and $Z_{2}$ as gamma distributed with common elements of shape and scale $\mathrm{k}_{0}$ (2), thereby ensuring certain commonality in risks of competing events under consideration;

- correlation coefficient $\rho$ between frailties $Z_{1}$ and $\mathrm{Z}_{2}$, evaluating competing risks commonalities;

- association between frailties $Z_{1}$ and $Z_{2}$ and frailty of terminal event $Z_{3}$ through common $Y_{0}$.

\section{Programming}

Implementation of competitive risk mixed proportional hazard (MPH) model was performed in statistical analytical system R for Mac OS X FAQ, v.3.1.0 2014-04-10, R.app 1.64 on the basis of platform MacPro OS X 10.9, 64-bit Intel Core i7 architecture. We used the package FRAILTYPACK (v.2.6), mostly module multivPenal. The latter operates the likelihood function, elements of which are copula derivatives, which are joint and margin- 
al survival functions with competing risk. Program script in $\mathrm{R}$ environment as follows:

options(digits=12)

if(!require("frailtypack"))stop("this test requires package frailtypack.”)

if(!require("survival"))stop("this test requires survival.")

if(!require("boot"))stop("this test requires boot.")

if(!require("MASS”))stop("this test requires MASS.”)

if(!require("survC1"))stop("this test requires survC1.")

cat("frailtypack test for multivariate model ....n")

CopulaData $<$ - read.table(“DataCompetingRisks.txt") attach(CopulaData)

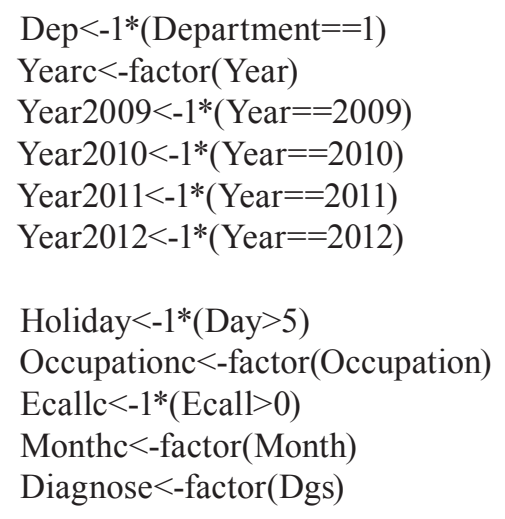

Copula.mode <- multivPenal(Surv(Between,Censored 1$) \sim$ cluster(ID) $+\mathrm{T}+$ Dep + Exigent + Order + Status1 + Holiday + Office + Age + Sex + Occupationc + CharlsonI + Ecallc + dStatus + Monthc + Diagnose1 + event2(Censored2) + terminal(Censored3),

formula.Event $2=\sim \mathrm{T}+$ Exigent + Status $2+$ Holiday + Office + Age + Sex + Occupationc + CharlsonI + Ecallc + dStatus + Monthc + Diagnose2, formula. terminalEvent $=\sim$ Age, data $=$ CopulaData, initialize=TRUE, hazard $=$ "Weibull")

summary(Copula.mode, level $=0.95)$

detach(CopulaData)

Three competing risks represented by three equations, dependent variables are so cold survival objects with censoring type created by function $\operatorname{Surv}()$. The latter make use of LBA and censoring indicator variables as parameters. For both types of admission we dealt with right censoring, indicated by variables Censoredl and Censored2.

Besides, each linear predictor includes "risk adjustment" resulting from competing events. That is why, say, linear predictor of admission risk due to the same cause includes survival objects event2(Censored2) and terminal(Censored3), by which allowance for competing risk (correction) processed. The same goes with linear predictor of risk of admission due to different cause. On account of terminal event, its predictor comprises (though not so obviously) frailties of competing events, regression effects of which represented in results with parameters Alphal and Alpha2. The model is formed as MPH model with Weibull density for basic hazard distribution.

\section{Results}

First let's look at the LBA distribution across contingents of patients (Table 1). Some regularities transpired, of the top interest is lengthening in mean LBA from 513 to 583 days with longer hospital stays. Medians follow the suit but less pronounced.

Therapeutic patients demonstrated longer LBA juxtapose to those treated in specialized departments (573 against 473 days in means and 559 against 470 days in medians).

The patients in severe condition experienced expected shorter LBA then moderate ones both in means (547 days vs. 579 days) and in medians (497 days vs. 580 days).

Social group belonging displayed conspicuous discrepancy in LBA with pensioners and unemployed having shortest means (552 and 557 days) while employed demonstrating 717 days.

The given regularities are expected and support consistency of data.

Table 1

LBA distribution across contingents of patients

\begin{tabular}{|c|c|c|c|c|}
\hline Contingents & Mean & $10 \%$ & Median & $90 \%$ \\
\hline Staying less then 10 days & 512,9 & 45 & 491 & 1030 \\
\hline Staying from 10 to 20 days & 569,8 & 83 & 558 & 1005 \\
\hline Staying above 20 days & 583,5 & 86 & 553 & 1014 \\
\hline Therapeutic department & 572,9 & 89 & 559 & 1012 \\
\hline Specialized department & 472,7 & 26 & 470 & 778 \\
\hline Age below 50 & 576,7 & 52 & 558 & 991 \\
\hline Age above 50 & 563,4 & 70 & 548 & 1020 \\
\hline Males & 575,7 & 104 & 559 & 1020 \\
\hline Females & 561,0 & 73 & 548 & 1001 \\
\hline Moderate condition & 579,2 & 88 & 580 & 1005 \\
\hline Severe condition & 547,0 & 72 & 497 & 1009 \\
\hline Planned admission & 583,1 & 72 & 579 & 1022 \\
\hline Emergent admission & 549,4 & 89 & 500 & 991 \\
\hline $\begin{array}{l}\text { Attended by chair of } \\
\text { department }\end{array}$ & 537,0 & 164 & 479 & 985 \\
\hline $\begin{array}{l}\text { Attended by regular } \\
\text { physician }\end{array}$ & 572,8 & 79 & 572 & 1020 \\
\hline Unemployed & 556,9 & 258 & 525 & 957 \\
\hline Employed & 717,5 & 59 & 828 & 1103 \\
\hline Student & 652,6 & 20 & 742 & 1088 \\
\hline Pensioner & 552,2 & 61 & 533 & 997 \\
\hline Total & 567,4 & 85 & 554 & 1007 \\
\hline
\end{tabular}

Parameter evaluation of competing risk model is displayed in Table 2. For convenience of interpretation we put regression coefficients $\theta$ of accelerated failure time model taking into consideration a Weibull density for failure times with hazard $h\left(t_{i} \mid x_{i}\right)=\lambda \kappa t^{\kappa-1} \exp \left(\beta x_{i}\right)$. The AFT regression takes the form [6]:

$$
\log \left(t_{i}\right)=-\frac{\log \lambda}{k}-\frac{\beta_{1}}{k} x_{1 i} \cdots-\frac{\beta_{p}}{k} x_{p i}+\frac{u_{i}}{k},
$$


so that

$$
\theta_{\mathrm{j}}=\exp \left(-\frac{\beta_{\mathrm{j}}}{\mathrm{k}}\right)
$$

derived from MPH regression coefficients $\beta_{\mathrm{j}}$ and clearly express the regression effects of factors $\mathbf{X}$ on LBA.

The main hypothesis stipulating influence of length of hospital staying on LBA is accepted for next admission due to same cause but rejected for different cause.

In case of same cause admission Z-test scored 1,957 with $p=0,025$. The effect magnitude $\theta=1,024 \mathrm{im}$ plies that each additional day of hospital staying ensures 2,5\% gain in LBA adjusted for other observed factors in a model, unobservable frailty of patient and competing risk biases. Therefore, in our situation lengthier hospital staying indeed safeguarded quality. The effect is negated in case next admission is due to different cause from previous with $Z$ scoring $0,128, p_{2}=0,449$. Still effect is positive $(\theta=1,014)$. We think it's important for validation of deduction, so far as better quality reduces commonality $\mathrm{Y}_{0}$, that constitutes each event frailty (2).

Correlation between frailties of competing risks ( $\rho$ ) proved to be highly significant $(\mathrm{p}<0,0001)$ with value of 0,627 , demonstrating substantial share of $Y_{0}$ in $Y_{0}+Y_{1}$ and $Y_{0}+Y_{2}$ (2). This supports necessity of competing risk frame in a model and substantial mutual determination of competing risks.

Table 2

Parameter evaluation of competing risk model

\begin{tabular}{|c|c|c|c|c|c|c|c|c|c|}
\hline \multirow{2}{*}{ Parameter } & \multirow{2}{*}{ Effect } & \multicolumn{4}{|c|}{ Admission due to same cause } & \multicolumn{4}{|c|}{ Admission due to different cause } \\
\hline & & $\theta_{1}$ & $\mathrm{~m}_{1}$ & $\mathrm{Z}_{1}$ & $\mathrm{p}_{1}$ & $\theta_{2}$ & $\mathrm{~m}_{2}$ & $\mathrm{Z}_{2}$ & $\mathrm{p}_{2}$ \\
\hline 1 & 2 & 3 & 4 & 5 & 6 & 7 & 8 & 9 & 10 \\
\hline Intercept & & 529 & 55,62 & 9,51 & 0,0001 & 553 & 89,04 & 6,21 & 0,0001 \\
\hline $\mathrm{T}$ & Length of staying & 1,024 & 0,012 & 1,96 & 0,025 & 1,014 & 0,109 & 0,13 & 0,449 \\
\hline Dep & Department & 1,197 & 0,019 & 9,47 & 0,0001 & $3 / 4$ & $3 / 4$ & $3 / 4$ & $3 / 4$ \\
\hline Exigent & Emergent admission & 0,901 & 0,089 & 1,17 & 0,122 & 0,988 & 0,043 & 0,28 & 0,390 \\
\hline Status & $\begin{array}{l}\text { Condition at admis- } \\
\text { sion }\end{array}$ & 0,960 & 0,022 & 1,87 & 0,031 & 0,911 & 0,078 & 1,19 & 0,117 \\
\hline Holiday & Admission at holiday & 0,925 & 0,070 & 1,11 & 0,133 & 1,003 & 0,065 & 0,05 & 0,479 \\
\hline Office & $\begin{array}{l}\text { Attended by regular } \\
\text { physician }\end{array}$ & 1,097 & 0,018 & 5,12 & 0,0001 & 1,134 & 0,114 & 1,10 & 0,135 \\
\hline Age & & 0,976 & 0,002 & 10,61 & 0,0001 & 0,958 & 0,011 & 3,91 & 0,0001 \\
\hline Age* & $\begin{array}{c}\text { Age in lethality } \\
\text { equation }\end{array}$ & 0,969 & 0,015 & 2,1 & 0,019 & $3 / 4$ & $3 / 4$ & $3 / 4$ & $3 / 4$ \\
\hline Sex & Male & 1,062 & 0,041 & 1,48 & 0,070 & 1,009 & 0,043 & 0,21 & 0,417 \\
\hline Occupationc2 & Student & 1,221 & 0,112 & 1,78 & 0,038 & 1,083 & 0,028 & 2,86 & 0,002 \\
\hline Occupationc3 & Pensioner & 1,139 & 0,134 & 0,97 & 0,166 & 1,018 & 0,014 & 1,29 & 0,099 \\
\hline Occupationc4 & Unemployed & 0,967 & 0,092 & 0,37 & 0,356 & 1,005 & 0,012 & 0,42 & 0,338 \\
\hline CharlsonI & $\begin{array}{c}\text { Charlson comorbidity } \\
\text { index }\end{array}$ & 0,901 & 0,123 & 0,85 & 0,197 & 0,794 & 0,104 & 2,22 & 0,013 \\
\hline Ecallc & Emergency calls & 1,118 & 0,219 & 5,10 & 0,0001 & 1,303 & 0,345 & 3,78 & 0,0001 \\
\hline dStatus & Improvement & 0,900 & 0,092 & 1,15 & 0,125 & 1,002 & 0,112 & 0,02 & 0,493 \\
\hline Monthc2 & February & 1,007 & 0,129 & 0,05 & 0,478 & 1,000 & 0,022 & 0,005 & 0,498 \\
\hline Monthc3 & March & 1,006 & 0,450 & 0,01 & 0,495 & 1,001 & 0,001 & 0,81 & 0,207 \\
\hline Monthe4 & April & 1,001 & 0,011 & 0,13 & 0,450 & 1,004 & 0,023 & 0,18 & 0,429 \\
\hline Monthc5 & May & 1,001 & 0,047 & 0,03 & 0,488 & 1,002 & 0,072 & 0,03 & 0,489 \\
\hline Monthc6 & June & 1,011 & 0,034 & 0,32 & 0,373 & 1,023 & 0,092 & 0,25 & 0,401 \\
\hline Monthc7 & July & 1,001 & 0,015 & 0,07 & 0,473 & 1,003 & 0,012 & 0,28 & 0,388 \\
\hline Monthc8 & August & 1,023 & 0,017 & 1,31 & 0,094 & 1,028 & 0,022 & 1,27 & 0,102 \\
\hline Monthc9 & September & 1,013 & 0,036 & 0,34 & 0,365 & 1,006 & 0,073 & 0,08 & 0,467 \\
\hline Monthc10 & October & 1,012 & 0,057 & 0,21 & 0,417 & 1,007 & 0,024 & 0,29 & 0,385 \\
\hline Monthc11 & November & 0,982 & 0,081 & 0,23 & 0,410 & 0,968 & 0,078 & 0,42 & 0,336 \\
\hline Monthc12 & December & 0,979 & 0,076 & 0,27 & 0,392 & 1,009 & 0,032 & 0,28 & 0,389 \\
\hline Diagnose 1 & MI & 0,842 & 0,036 & 4,81 & 0,0001 & 1,409 & 0,102 & 3,36 & 0,0001 \\
\hline Diagnose2 & Hypertension & 1,000 & 0,055 & 0,005 & 0,498 & 0,652 & 0,261 & 1,64 & 0,051 \\
\hline Diagnose3 & CHD & 0,992 & 0,063 & 0,13 & 0,449 & 0,496 & 0,309 & 2,27 & 0,012 \\
\hline Diagnose4 & Stroke & 0,875 & 0,012 & 11,17 & 0,0001 & 1,637 & 0,126 & 3,91 & 0,0001 \\
\hline Diagnose5 & Poisoning & 1,000 & 0,076 & 0,003 & 0,499 & 1,357 & 0,191 & 1,60 & 0,055 \\
\hline Diagnose6 & Pneumonia & 0,762 & 0,035 & 7,77 & 0,0001 & 0,441 & 0,398 & 2,06 & 0,020 \\
\hline Diagnose7 & Peptic ulcer & 1,045 & 0,021 & 2,09 & 0,018 & 1,005 & 0,074 & 0,07 & 0,473 \\
\hline Diagnose 8 & Allergy & 0,820 & 0,074 & 2,69 & 0,004 & 0,974 & 0,105 & 0,25 & 0,402 \\
\hline Diagnose9 & Kidney disease & 0,878 & 0,043 & 3,02 & 0,001 & 1,164 & 0,097 & 1,57 & 0,059 \\
\hline Diagnose10 & CLD & 0,794 & 0,011 & 21,00 & 0,0001 & 1,003 & 0,118 & 0,02 & 0,490 \\
\hline
\end{tabular}


Continuation of Table 2

\begin{tabular}{|c|c|c|c|c|c|c|c|c|c|}
\hline 1 & 2 & 3 & 4 & 5 & 6 & 7 & 8 & 9 & 10 \\
\hline Diagnose11 & Chr. pancreatitis & 0,842 & 0,078 & 2,20 & 0,014 & 1,010 & 0,093 & 0,11 & 0,457 \\
\hline Diagnose12 & Tumor & 0,875 & 0,029 & 4,62 & 0,0001 & 1,148 & 0,107 & 1,29 & 0,099 \\
\hline Diagnose13 & Liver disease & 0,762 & 0,111 & 2,45 & 0,007 & 0,969 & 0,096 & 0,32 & 0,373 \\
\hline Diagnose14 & Gynecological d. & 1,195 & 0,093 & 1,91 & 0,028 & 1,425 & 0,201 & 1,76 & 0,039 \\
\hline Diagnose15 & Bronchitis & 0,758 & 0,058 & 4,78 & 0,0001 & 1,006 & 0,117 & 0,05 & 0,479 \\
\hline Diagnose16 & Anemia & 0,878 & 0,077 & 1,69 & 0,046 & 1,370 & 0,146 & 2,16 & 0,015 \\
\hline Diagnose17 & Rheumatism & 0,870 & 0,033 & 4,21 & 0,0001 & 1,406 & 0,193 & 1,77 & 0,039 \\
\hline Diagnose18 & Flue complication & 0,855 & 0,051 & 3,08 & 0,001 & 1,338 & 0,140 & 2,08 & 0,019 \\
\hline Diagnose19 & Diabetes & 0,842 & 0,021 & 8,19 & 0,0001 & 1,156 & 0,109 & 1,33 & 0,092 \\
\hline Diagnose20 & VD & 1,096 & 0,042 & 2,19 & 0,014 & 1,331 & 0,116 & 2,47 & 0,007 \\
\hline Diagnose21 & Joints disease & 0,831 & 0,092 & 2,01 & 0,022 & 1,353 & 0,156 & 1,94 & 0,026 \\
\hline Diagnose22 & Other & 0,855 & 0,033 & 4,76 & 0,0001 & 1,339 & 0,173 & 1,69 & 0,046 \\
\hline Theta(1,2) & $\begin{array}{c}\text { Admission frailties } \\
\text { variance }\end{array}$ & 2,784 & 0,127 & 8,06 & 0,0001 & 4,255 & 0,241 & 6,01 & 0,0001 \\
\hline Theta3 & $\begin{array}{c}\text { Lethality frailty } \\
\text { variance }\end{array}$ & 1,610 & 0,078 & 6,10 & 0,0001 & $3 / 4$ & $3 / 4$ & $3 / 4$ & $3 / 4$ \\
\hline Alpha(1,2) & $\begin{array}{c}\text { Admission frail- } \\
\text { ties regr. coeff. on } \\
\text { lethality }\end{array}$ & 0,236 & 0,197 & 1,20 & 0,115 & 2,950 & 0,144 & 14,24 & 0,0001 \\
\hline Rho & Correlation $\rho$ (f.3) & 0,627 & 0,156 & 4,02 & 0,0001 & $3 / 4$ & $3 / 4$ & $3 / 4$ & $3 / 4$ \\
\hline Scale(1,2) & Scale param. (f.2) & 6,074 & $3 / 4$ & $3 / 4$ & $3 / 4$ & 3,912 & $3 / 4$ & $3 / 4$ & $3 / 4$ \\
\hline Scale3 & $\begin{array}{c}\text { Scale for gamma dis- } \\
\text { tr. of lethality frailty }\end{array}$ & 7,330 & $3 / 4$ & $3 / 4$ & $3 / 4$ & $3 / 4$ & $3 / 4$ & $3 / 4$ & $3 / 4$ \\
\hline Shape(1,2) & Shape param.(f.2) & 0,864 & $3 / 4$ & $3 / 4$ & $3 / 4$ & 0,729 & $3 / 4$ & $3 / 4$ & $3 / 4$ \\
\hline Shape3 & $\begin{array}{c}\text { Shape for gamma dis- } \\
\text { tr. of lethality frailty }\end{array}$ & 0,949 & $3 / 4$ & $3 / 4$ & $3 / 4$ & $3 / 4$ & $3 / 4$ & $3 / 4$ & $3 / 4$ \\
\hline
\end{tabular}

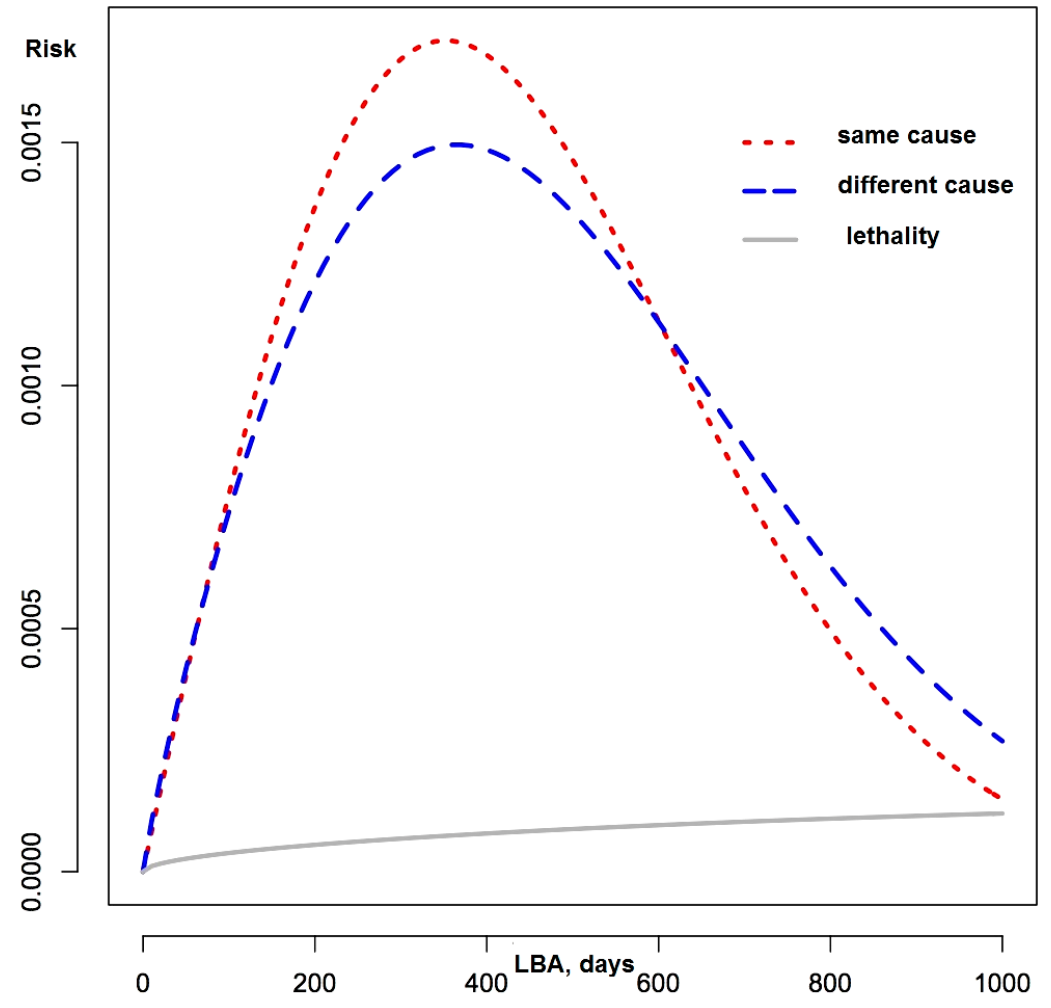

Fig. 2. Basic risks density functions

High significance $(\mathrm{p}<0,0001)$ obtained for regression coefficient for frailty of admission due to different cause in lethality equation valued 2,950. It advocates appropriateness of inclusion of terminal event risk in model construct. Besides, age appeared to be significant moderator of lethality with effect of 0,969 $(p=0,019)$, so that each year of age marginally augments risk of terminal event by $3,1 \%$.

Aforementioned Weibull distribution of competing basic hazards has shape and scale parameters. Their estimates (Shape1Shape2 and Scale1-Scale2) bare evidence of similarity of competing basic risks distributions. Latter skewed to the right. Distribution density of terminal event is rather different and demonstrated small augmentation with time (Fig. 2).

\section{Discussion}

It goes without saying that physicians are subject to market forces like other workers, so the prices chosen by health plans are probably best regarded as being determined by demand and supply [7]. Workload is another matter. The confine possibility to third parties' contracting on outcomes (despite of instances the patient observes a qualities related) means that physicians are certain to remain with discretion about quantities, even when measured in simple terms like "hours spent" on various activities. Economic models, abstracting the complexity of medical decisions into a single dimension of "quantity," give the impression that treatment decisions are more easily monitored and controlled than they really are $[8,9]$. Acknowledging the many 
elements composing treatment - the many inputs, the sequence of events, the observable and the behind-the scenes "paraclinical" activities - leads inevitably to the conclusion that the simple monitoring and incentives devices used by payers leave a great deal of authority about treatment with the physician [10]. The peculiarity of health market structures of transitional economics is insufficient monopsony power of payer, leaving much discretion to physician to take care of her utilities. No wonder that our findings supported the hypothesis on discretionary power of physician in tune with numerous researches [9-12].

The closest empirical model and findings pertained to researchers who studied changes of physician practices as response to transition from fee for services (FFS) based remuneration to mixt of FFS and hourly based salary $[2,13]$. The situation is somewhat similar but drop in marginal profit for administered procedure (p) was compensated by hourly payment (w).

Theoretical model also differed and described narrower set of possibilities according to particular situation. They proceeded with derivatives of simultaneous structural equations. To elucidate effects of transition to mixt remuneration they analyzed derivatives by $p$ and $\mathrm{w}$ with the help of Slutsky decomposition. The researchers deduced that partial effect of drop in marginal income for administered procedure entailed reduction of physician's effort that is verbatim of our model based inference.

Derivatives by $w$ substantiated deduction on negativity of compensated effect of increase in $w$ on physician's effort to produce services. This goes hand in hand with our conclusion. It is straight from our model that introduction of hourly based salary (counterbalancing compensation with cross-price negative effects) motivates physician to increase non-clinical hours in lieu of clinical hours $[3,13]$.

The reduction in physician's efforts was expected both by compensated effect and by income effect that is in tune with our conclusions. The beneficial features of our model and related deductions are generality and much more simplified reckoning and interpretation [14].

\section{Conclusion}

We questioned the possibility of hampered quality of hospital treatment in less competitive environment from physician behavior perspective. The theoretical model suggests deterioration in quality due to substitution of paraclinical hours by clinical hours. Paraclinical hours can be viewed as add-on value to quality, for instance, a physician may have to perform a minimal level of administrative tasks in order to properly treat his/her patients or to access some health-care establishment's equipment, do consulting or other activities to support better case management. According to theoretical model the patient's length of staying in hospital is likely to increase (more time per service in hospital) but the risk of re-admission post-discharge may decrease (higher quality of services received when hospitalized). If the current reform had only an effect on the reallocation of tasks toward less clinical and more paraclinical activities without quality impairment, the length of staying in hospital is expected to increase, but with little impact on the risk of re-admission.

To elucidate the dilemma we referred to natural experiment. In a process of health reform in city Vinnitsa load of patients per physician increased dramatically in some city hospitals with parallel monopolization in hospital care tailoring.

Our findings tentatively supports deterioration in quality surely enough for subsequent admissions due to same cause.

Our results raise an important issue regarding the measure of health care services quality. Does an increase in the risk of readmission to hospital necessarily indicate a reduction in the quality of these services? We believe that this case is not necessary. For instance, for a given diagnosis, physicians who spend more time with their patients in hospital may also be more inclined to rehospitalise them in order to provide them with a better treatment. A natural research extension of our paper could thus be to compare the evolution of health status of several cohorts of patients with a same diagnosis but treated in different economic environment (e. g. different insurance policies).

\section{References}

1. Ocheredko, O. M. Econometric model of physician behavior in hospitals with empirical verification under reform of medical care in Vinnitsa town [Text] / O. M. Ocheredko, I. V. Yaremena // Actual problems of clinical and preventive medicine. - 2014. Vol. 2, Issue 1. - P. 3-12.

2. Echevin, D. Physician Payment Mechanisms, Hospital Length of Stay and Risk of Readmission: a Natural Experiment [Text] / D. Echevin, B. Fortin // SSRN Electronic Journal. - 2011. - Issue 11-12. doi: 10.2139/ssrn.1825207

3. Fortin, B. Policy Analysis in the Health-Services Market: Accounting for Quality and Quantity [Text] / B. Fortin, N. Jacquemet, B. Shearer // Annales d'Economie et de Statistiques. - 2008. - Issue 91-92. - P. 293-319.

4. Yaremena, I. V. Study of influence of competition in duration hospitalization based field experiments [Text] / I. V. Yaremena // Experimental and clinical medicine. - 2015. - Issue 2 (67). - P. 155-161.

5. Cutler, D. The incidence of adverse medical outcomes under prospective payment [Text] / D. Cutler // Econometrica. 1995. - Vol. 63, Issue 1. - P. 29-50. doi: 10.2307/2951696

6. Keiding, N. The role of frailty models and accelerated failure time models in describing heterogeneity due to omitted covariates [Text] / N. Keiding, P. Andersen, J. Klein // Statistics in Medicine. - 1997. - Vol. 16, Issue 2. - P. 215-224. doi: 10.1002/(sici)10970258(19970130)16:2<215::aid-sim481>3.3.co;2-a

7. Folland, S. The economics of health and health care [Text] / S. Folland, A. C. Goodman, M. Stano. - London: Routledge, 2012. -624 p. 
8. Gaynor, M. Competition among Hospitals [Text] / M. Gaynor, W. B. Vogt // The RAND Journal of Economics. - 2003. Vol. 34, Issue 4. - P. 764-785. doi: 10.2307/1593787

9. Grytten, J. Patient choice and access to primary physician services in Norway [Text] / J. Grytten, R. J. Sorensen // Health Economics, Policy and Law. - 2008. - Vol. 4, Issue 01. - P. 11-27. doi: 10.1017/s1744133108004623

10. McGuire, T. G. Physician Agency. Chep. 9 [Text] / T. G. McGuire // Handbook of Health Economics. - Amsterdam: Elsevier, 2000. - P. 461-536. doi: 10.1016/s1574-0064(00)80168-7

11. Gaynor, M. Moral Hazard and Risk Spreading in Partnerships [Text] / M. Gaynor, P. Gertler // The RAND Journal of Economics. - 1995. - Vol. 26, Issue 4. - P. 591-614. doi: 10.2307/2556008

12. McGuire, T. G. Physician response to fee changes with multiple payers [Text] / T. G. McGuire, M. V. Pauly // Journal of Health Economics. - 1991. - Vol. 10, Issue 4. - P. 385-410. doi: 10.1016/0167-6296(91)90022-f

13. Echevin, D. Physician Payment Mechanisms, Hospital Length of Stay and Risk of Readmission: a Natural Experiment [Text] / D. Echevin, B. Fortin // SSRN Electronic Journal. - 2011. - Issue 44. doi: 10.2139/ssrn.1919071

14. Yaremena, I. V. Physician behavior in hospital in competitive environment [Text]: intern. conf. / I. V. Yaremena, O. M. Ocheredko // Biology and Medical Sciences. - Vienna, 2015. - P. 203-208.

Рекомендовано до публікаиії д-р мед. наук, професор Гойда Н. Г. Дата надходження рукопису 16.01.2017

Iryna Yaremyna, Assistant, Department of Social Medicine and Health Organization, National Pirogov Memorial Medical University, Pyrohova str., 56, Vinnitsa, Ukraine, 21018

E-mail: aria_adel@mail.ru

Ocheredko Oleksandr, Professor, Department of Social Medicine and Health Organization, National Pirogov Memorial Medical University, Pyrohova str., 56, Vinnitsa, Ukraine, 21018

E-mail: ocheredko@yahoo.com

УДК 616.37-006.6 -085.277.3-085 371

DOI: $10.15587 / 2519-4798.2017 .94302$

\title{
ЗАСТОСУВАННЯ ПРОТИПУХЛИННОЇ ВАКЦИНОТЕРАПІЇ НА ОСНОВІ ДЕНДРИТНИХ КЛІТИН В АД'ЮВАНТОНОМУ ЛІКУВАННІ ХВОРИХ НА РАК ПІДШЛУНКОВОї ЗАЛОЗИ
}

\author{
(․) О. І. Дронов, С. В. Земсков, Н. М. Храновська, О. В. Скачкова
}

Метою дослідження було вивчити вплив протипухлинної вакцинотерапії на основі дендритних клітин, навантажених механо-активованими аутологічними ліофілізованими пухлинниими клітинами (ДК-МАЛФПК-ПВТ) у складі ад ювантного лікування на загальну виживаність хворих на рак підшлункової залози (РПЗ). Дослідження провендено на 43 хворих, щзо отримували гемщитабін-вмісну ад’ювантну хіміотерапії. Застосування ДК-МАЛФПК-ПВТ значно підвищує загальну виживаність хворих на РПЗ

Ключові слова: рак підшлункової залози, протипухлинна вакцина, дендритні клітини, виживаність, імунна система

\section{1. Вступ}

Рак підшлункової залози (РПЗ) входить до сімки найпоширеніших раків та $є$ найагресивнішим серед всіх гастроінтестінальних раків. Більше 90 \% РПЗ представлено протоковою аденокарциномою. Серед сучасних підходів до лікування розглядають хірургічне, яке дає шанс на 5-річну виживаність не більше як 15-18 \% хворих, не зважаючи на ад'ювантне лікування. Хіміотерапія, ефект від якої відмічається приблизно у 40 \% хворих, привносить мінімальний вплив на виживаність. Роль радіотерапії активно дискутують: в європейських дослідженнях, на відміну від
США, їі ефект не доведено, а таргетна терапія для цієї локалізації не виправдала надій, покладених на неї ще 15 років тому. Таким чином, пошук нових підходів в лікуванні хворих на РПЗ з метою покращення їх виживаності сьогодні представляється дуже актуальним.

Однією з таких перспектив, на наш погляд, є імунотерапія, дія якої спрямована на налаштування або підсилення ефективної імунної відповіді (IB) проти пухлини. Цього можна досягти завдяки багатьом підходам, що включають вакцинацію, адоптивний перенос імунних клітин та імуномодуляцію 3 метою підсилення існуючої IB [1]. 